\title{
Decomposition of Arachis pintoi and Hyparrhenia rufa litters in monoculture and intercropped systems under lowland soil(1)
}

\author{
Christiane Abreu de Oliveira( ${ }^{(2)}$, Maria Rita Scotti Muzzi(2), Hortênsia Abrantes Purcino(3), \\ Ivanildo Evódio Marriel(4) and Nadja Maria Horta de Sá(2)
}

\begin{abstract}
Tropical grasslands under lowland soils are generally underutilized and the litter of forage legumes may be used to recover these degraded pastures. The objective of this work was to study the dynamics of litter decomposition of Arachis pintoi (pinto peanut), Hyparrhenia rufa (thatching grass) and a mixture of both species in a lowland soil. These treatments were analyzed in three areas: grass monoculture, legume monoculture and legume intercropped with the grass during the dry and wet seasons. Litter bags containing the legume, grass or a mixture of both species were incubated to estimate the decomposition rate and microorganism colonization. Decomposition constants $(\mathrm{K})$ and litter half-lives $\left(T_{1 / 2}\right)$ were estimated by an exponential model whereas number of microorganisms in specific media were determined by plate dilution. The decomposition rate, release of nutrients and microorganisms number, especially bacteria, increased when pinto peanut was added to thatching grass, influenced by favorable lignin/ $\mathrm{N}$ and $\mathrm{C} / \mathrm{N}$ ratios in legume litter. When pinto peanut litter was incubated in the grass plots, $50 \% \mathrm{~N}$ and $\mathrm{P}$ was released within about 135 days in the dry season and in the wet season, the equivalent release occurred within 20 days. These results indicate that $A$. pintoi has a great potential for nutrient recycling via litter and can be used to recover degraded areas.
\end{abstract}

Index terms: forage, microorganisms, pinto peanuts, soil organic matter, thatching grass.

Decomposição da serrapilheira de Arachis pintoi e Hyparrhenia rufa em sistemas de monocultura e consórcio sob solo de várzea

Resumo - Pastagens tropicais sobre solos de várzea são geralmente subutilizadas. A serrapilheira de leguminosas forrageiras pode ser usada para a recuperação destas pastagens. O objetivo deste trabalho foi estudar a dinâmica de decomposição de Arachis pintoi (arachis), Hyparrhenia rufa (capim jaraguá) e da mistura destas espécies, em solo de várzea. Estes tratamentos foram analisados em três áreas: monocultivo da gramínea; monocultivo da leguminosa e no consórcio entre as espécies durante as estações seca e chuvosa. Sacos de decomposição contendo a serrapilheira da leguminosa ou da mistura das espécies foram incubados para estimar a taxa de decomposição e colonização microbiana. A taxa de decomposição e o tempo de meia-vida $\left(\mathrm{T}_{1 / 2}\right)$ foram estimados por um modelo exponencial, e o número de microrganismos foi determinado por meio de diluição em placas em meios específicos. A liberação de nutrientes, a taxa de decomposição, e o número de microrganismos, especialmente bactérias, aumentaram quando arachis foi adicionado ao capim jaraguá, com influência da relação favorável de lignina/ $\mathrm{Ne} C / \mathrm{N}$ do resto desta cultura. Quando arachis foi incubado em parcelas de monocultivo da gramínea, 50\% do total de $\mathrm{N}$ e $\mathrm{P}$ foi liberado em 135 dias na estação seca e em 20 dias na estação chuvosa. Estes resultados indicam que $A$. pintoi tem um grande potencial para ciclagem de nutrientes e pode ser uma estratégia na recuperação de áreas degradadas.

Termos para indexação: forrageiras, microrganismo, arachis, matéria orgânica do solo, capim jaraguá.

(1) Accepted for publication on June 23, 2003.

(2) Universidade Federal de Minas Gerais, Instituto de Ciências Biológicas, Dep. de Botânica, Pampulha, Caixa Postal 486, CEP 31270-901 Belo Horizonte, MG, Brasil. E-mail: ampaiva@netzero.net, mrita@mono.icb.ufmg.br, nadja@icb.ufmg.br

${ }^{(3)}$ Empresa de Pesquisa Agropecuária de Minas Gerais, Fazenda Experimental Santa Rita, Caixa Postal 295, CEP 35700-000 Sete Lagoas, MG, Brasil. E-mail: corsetti@cnpms.embrapa.br

(4) Embrapa-Centro Nacional de Pesquisa de Milho e Sorgo, Caixa Postal 151, CEP 35701-970 Sete Lagoas, MG, Brasil. E-mail: imarriel@cnpms.embrapa.br

\section{Introduction}

The grasslands of Brazilian lowlands frequently suffer from pasture deterioration and degradation due mainly to frequent inundation (Ferguson, 1992). The causes of this degradation include low aeration, overgrazing, occasional attacks from pests and diseases and especially $\mathrm{N}$ and $\mathrm{P}$ deficiencies (Macedo, 1995; Thomas, 1995). In these cases, recent evidence has shown that the return of plant nutrients to the soil via litter is a very important process (Thomas, 1992). 
The litter of forage legumes may be used to recover the soil, protecting it from erosion, increasing $\mathrm{N}$ mineralization efficiency, decreasing $\mathrm{C} / \mathrm{N}$ ratios and adding $\mathrm{P}$ to soils. On the other hand, recycling via litter of forage legumes to improve the physical, chemical and biological properties of soils would yield better results if legume species were chosen in such a way as to allow a degree of synchrony between supply and uptake by growing plants (Thomas \& Asakawa, 1993; Myers et al., 1997).

Decomposition and nutrient release patterns of organic materials are determined by the organic constituents and nutrient content of the material, the decomposer organisms present, and the environmental conditions (Swift, 1976; Palm \& Sanchez, 1991; Heal et al., 1997). Soil microflora, including fungi, bacteria and actinomycetes, is responsible for the biochemical processes involved in decomposition of plant residues and nutrient $(\mathrm{N}, \mathrm{P}, \mathrm{S})$ release (Smith, 1994; Wardle et al., 1999).

The forage legume Arachis pintoi has been suggested as one of the best alternatives for pastures on poorly drained soils and pasture subjected to excessive grazing. This legume has faster rates of decomposition and a greater release of nutrients (Thomas, 1993). In order to develop a management of grasslands under lowland soils, knowledge of the decomposition characteristics and nutrient release is required.

The objective of this work was to study the decomposition and nutrient release rates of Arachis pintoi and Hyparrhenia rufa litters, both as single and mixed-species, in monoculture and intercropped systems under a lowland soil, during dry and wet seasons.

\section{Material and Methods}

The experiments were carried out on pastures established since 1993 in a lowland soil at Santa Rita Experimental farm, Sete Lagoas, MG, Brazil, situated at $732 \mathrm{~m}$ above sea level, $19^{\circ} 38^{\prime} \mathrm{S}, 45^{\circ} \mathrm{W}$, during the dry (March to July, 1999) and wet (October 1999 to February 2000) seasons. The average temperature during the day throughout the experimental period was $18^{\circ} \mathrm{C}$ during dry season and $26^{\circ} \mathrm{C}$ during wet season, and mean annual rainfall was $55 \mathrm{~mm}$ during dry season and 1,350 mm during wet season. The soil was a hydromorphic clay (Gleissolo), clay texture ( $72 \%$ clay, $19 \%$ silt, $9 \%$ sand), with mean values of $\mathrm{pH} 5.1,36 \%$ aluminum saturation, $10.1 \mathrm{~g} \mathrm{~kg}^{-1}$ organic $\mathrm{C}, 9 \mathrm{mg} \mathrm{dm}^{-3}$ available $\mathrm{P}$ (Mehlich-1), $1.5 \mathrm{mg} \mathrm{dm}^{-3}$ total $\mathrm{N}, 1.67 \mathrm{cmol}_{\mathrm{c}} \mathrm{kg}^{-1} \mathrm{Ca}, 0.39 \mathrm{cmol}_{\mathrm{c}} \mathrm{kg}^{-1}$ $\mathrm{Mg}$ and $0.58 \mathrm{cmol}_{\mathrm{c}} \mathrm{kg}^{-1} \mathrm{~K}$.

Pesq. agropec. bras., Brasília, v. 38, n. 9, p. 1089-1095, set. 2003
Litter decomposition rates and microorganism colonization were determined using $1.5 \mathrm{~mm}$ mesh nylon litter bags containing $15 \mathrm{~g}$ of three different plant residues (Arachis pintoi (pinto peanut) litter, Hyparrhenia rufa (thatching grass) litter, and a mixture of both litters at a 1:1 ratio). The litter bags were placed on the soil surface and covered with a layer of litter from the appropriate species for 120 days in the dry season and 80 days during the wet season in pasture plots. Bags were emptied at 20 day intervals, the material was dried at $60^{\circ} \mathrm{C}$ to constant weight and analyzed for total P (Sarruge \& Haag, 1974), and Kjeldahl digestion was performed to determine total $\mathrm{N}$ (Oliveira, 1986). Ash free dry weight and total C was determined after combustion at $500^{\circ} \mathrm{C}$ for three hours (Wesemael, 1993). Lignin and cellulose contents were determined by the acid detergent fiber method (Soest, 1963).

Decay rate constant $(\mathrm{K})$, and half life $\left(\mathrm{T}_{1 / 2}\right)$ were calculated from percent remaining dry weight using the single negative exponential decay function according to Olson (1963). The same model was used to calculate the decay rate constant of $\mathrm{N}$ and $\mathrm{P}(\mathrm{KN}, \mathrm{KP})$ and the half-lives of $\mathrm{N}$ and $\mathrm{P}$ release $\left(\mathrm{T}_{1 / 2} \mathrm{~N}, \mathrm{~T}_{1 / 2} \mathrm{P}\right)$.

The microbial populations of the residues were assessed using a residue washing technique (Chang \& Hudson, 1967). The residues were diluted and incorporated into specific medium for each group of microorganisms (Parkinson et al., 1971).

The experimental design was a randomized complete block in a scheme of subdivided plot, with three replications comprising the following plots: monocultive stand of pasture of grass, monocultive stand of legume and intercropped stand of legume plus grass. The split plots consisted of bags containing three different litters. The split plots consisted of different harvest times for the whole period of the experiment. The plot $\mathrm{x}$ split plot interaction corresponds to the environment of bag incubation and bag content (plot/litter bag), for a total of nine treatments: pinto peanut/pinto peanut, pinto peanut/mixture, pinto peanut/grass, mix/pinto peanut, mix/mixture litter, mix/grass, grass/pinto peanut, grass/mixture, grass/grass.

The data were submitted to normalization and analysis of variance, analysis of correlation and the means were compared by the Tukey test at $5 \%$ significance level (MSTATc program, Michigan State University, MI, USA).

\section{Results and Discussion}

Initial quality of legume (A. pintoi) litter and grass ( $H$. rufa) and the mixture of both species are shown in Table 1. During both seasons, the concentrations of $\mathrm{N}$ and $\mathrm{P}$ of the legume were higher than those of the grass, at dry and wet season. The $\mathrm{C} / \mathrm{N}$ ratio of the grass litter was the highest, followed by the mix- 
ture of litter and legume. The lignin/ $\mathrm{N}$ ratio and cellulose contents were higher for grass.

Decomposition constants $(\mathrm{K})$ and litter half-lives $\left(T_{1 / 2}\right)$ were similar during the dry season (Table 2$)$. However, significant differences were observed among the treatments in the wet season, probably due to favorable conditions for decomposition, such as high soil humidity and high temperatures. The decomposition constant and dry matter weight loss of the thatching grass were increased when pinto peanut litter was present, especially in grass monoculture stands during the wet season. Probably this fact was influenced by the lower initial $\mathrm{C} / \mathrm{N}$ ratio of this legume and the higher microbial activity found in these litters (Table 3). It is known that litter decomposition depends on the initial values of the $\mathrm{C} / \mathrm{N}$ and lignin/ $\mathrm{N}$ ratios, and the cellulose contents (Entry \& Backman, 1995; Wardle \& Lavelle, 1997; Tian, 1998). The K values agree with those reported by Thomas \& Asakawa (1993) in Colombian soils (sa-

Table 1. Initial litter composition of Arachis pintoi (peanut), Hyparrhenia rufa (grass) and mixture (peanut + grass) during dry and wet season in litter bags with $15 \mathrm{~g}$ of plant residue in each bag.

\begin{tabular}{ccccccc}
\hline Season & C/N & Lignin/N & N & P & Lignin & Cellulose \\
& \multicolumn{7}{c}{--- (mg/litter bag) --- } \\
\hline \multicolumn{7}{c}{ Arachis pintoi } \\
Dry & 38.7 & 3.74 & 368.5 & 61.0 & 9.2 & 27.3 \\
Wet & 36.3 & 1.97 & 393.0 & 61.0 & 5.2 & 20.4 \\
\hline \multicolumn{7}{c}{ Mixture } \\
Dry & 62.6 & 5.28 & 221.7 & 41.2 & 7.5 & 33.4 \\
Wet & 61.3 & 4.07 & 227.5 & 41.3 & 6.2 & 30.2 \\
\hline \multicolumn{7}{c}{ Hyparrhenia rufa } \\
Dry & 180.2 & 12.86 & 74.95 & 21.5 & 5.8 & 39.6 \\
Wet & 222.4 & 17.61 & 61.5 & 21.5 & 7.2 & 39.5 \\
\hline
\end{tabular}

Table 2. Decomposition rate (K), half time decomposition $\left(\mathrm{T}_{1 / 2}\right)$, in litter of Arachis pintoi (peanut), Hyparrhenia rufa (grass) and mixture (peanut + grass), in single and mix plots after incubation for 160 and 80 days during the dry and wet seasons, respectively ${ }^{(1)}$.

\begin{tabular}{lccccc}
\hline \multirow{2}{*}{$\begin{array}{l}\text { Treatment } \\
\text { (plot/litter bag) }\end{array}$} & \multicolumn{2}{c}{$\mathrm{K}\left(\right.$ day $\left.^{-1}\right)$} & & \multicolumn{2}{c}{$\mathrm{T}_{1 / 2}$ (days) } \\
\cline { 2 - 3 } \cline { 5 - 6 } pry & Wet & & Dry & Wet \\
\hline Peanut/peanut & 0.0028 & $0.0334 \mathrm{a}$ & & 245.51 & $20.76 \mathrm{c}$ \\
Peanut/mixture & 0.0022 & $0.0233 \mathrm{ab}$ & & 318.04 & $29.68 \mathrm{c}$ \\
Peanut/grass & 0.0022 & $0.0104 \mathrm{~cd}$ & & 320.47 & $66.81 \mathrm{a}$ \\
Mixture/peanut & 0.0022 & $0.0271 \mathrm{ab}$ & & 320.88 & $25.61 \mathrm{c}$ \\
Mixture/mixture & 0.0025 & $0.0184 \mathrm{bc}$ & & 274.72 & $37.68 \mathrm{bc}$ \\
Mixture/grass & 0.0016 & $0.0110 \mathrm{~cd}$ & & 429.07 & $62.78 \mathrm{ab}$ \\
Grass/peanut & 0.0025 & $0.0340 \mathrm{a}$ & & 272.17 & $20.38 \mathrm{c}$ \\
Grass/mixture & 0.0021 & $0.0205 \mathrm{~b}$ & & 337.87 & $33.83 \mathrm{c}$ \\
Grass/grass & 0.0018 & $0.0083 \mathrm{~d}$ & & 376.15 & $83.44 \mathrm{a}$ \\
\hline
\end{tabular}

(1)Means followed by the same letter in each column did not differ significantly at $5 \%$ probability level by the Tukey test; the coefficients of variation for the decomposition rate and for the half time decomposition, both in the wet season, were $11.4 \%$ and $20.89 \%$, respectively. vannas) and were a little lower than those found in Brazilian "cerrado" soils (Oliveira et al., 2002). Differences found among lowland soil ( $72 \%$ clay, $19 \%$ silt, 9\% sand) results and Brazilian "cerrado" soils (a red yellow latossol with 55\% clay, $11 \%$ silt, $34 \%$ sand) may be related to soil texture. Lowland soils have high clay level, with low drainage and aeration capacity and tendency to flooding. The high clay values also favor the aggregate of organic matter to clay, limiting microbial access to organic substrate, resulting in slower decomposition speed (Heal et al., 1997). Similarly Groffman et al. (1996) suggest that soil texture is an important controller of changes in microbial activity in studies of grass decomposition in two soils with different textures (a silt loam, with $75-95 \%$ silt plus clay, a loamy sand with $15-40 \%$ silt plus clay and a coarse-silty, with $55-85 \%$ silt plus clay).

In general, in the wet period, the half-lives of decomposition in mixed litters and pinto peanuts litter were less than $50 \%$ of those of grass litter, probably due to higher temperatures and rainfall that can positively influence the rates of decomposition (Palm \& Sanchez, 1991; Thomas, 1995) by affecting microbial decomposition (Swift et al., 1979; Okeke \& Omaliko, 1992). During the initial period of the wet season the bacterial population was increased, probably contributing to the higher $\mathrm{K}$ values (Tables 2 and 3 ). The fungal population showed few changes in most treatments. The bacterial population increased after 120 days in the dry season and was markedly reduced after 80 days in the wet season, with exception of the treatments, grass/mixture and grass/grass. This was probably due to the intense flooding that occurred during the final period of the wet season, contributing to the low aeration of this soil. Fungal populations are more intimately associated with litter and soil (Wardle et al., 1999), and consequently are less susceptible to seasonal variation and low aeration (Cornejo et al., 1994) than bacteria during decomposition (Wardle et al., 1999). The cellulolytic populations were generally decreased after 80 days in the wet season and phosphate-solubilizing microorganisms were present in higher numbers in A. pintoi and mixed litters in the wet season in grass plots. The mixture of different substrates can favor the diversity of microorganisms. In "cerrado" soils (Oliveira et al., 2002) with the same litters, phosphate solubilizing microorganisms were also higher in pinto peanut litter in all plots. This observation confirms the affinity of these microorganisms for A. pintoi litter, which contains high 
Table 3. Number of colonies forming unite/g of dry litter of the microbial populations in litter bags with Arachis pintoi (peanut) litter, Hyparrhenia rufa (grass) litter, mixture (peanut + grass) litter, in single and intercropped plots during the dry and wet seasons ${ }^{(1)}$.

\begin{tabular}{|c|c|c|c|c|c|c|c|c|c|}
\hline \multirow{2}{*}{$\begin{array}{l}\text { Treatment } \\
\text { (plot/litter bag) }\end{array}$} & \multirow[t]{2}{*}{ Time $^{(2)}$} & \multicolumn{2}{|c|}{ Fungi } & \multicolumn{2}{|c|}{ Bacteria } & \multicolumn{2}{|c|}{ P. solubilizing } & \multicolumn{2}{|c|}{ Cellulolitic } \\
\hline & & $\begin{array}{l}\text { Dry } \\
\left(\mathrm{x} 10^{7}\right)\end{array}$ & $\begin{array}{c}\text { Wet } \\
\left(\times 10^{8}\right)\end{array}$ & $\begin{array}{l}\text { Dry } \\
\left(\mathrm{x} 10^{7}\right)\end{array}$ & $\begin{array}{c}\text { Wet } \\
\left(\mathrm{x} 10^{8}\right)\end{array}$ & $\begin{array}{c}\text { Dry } \\
\left(\mathrm{x} 10^{7}\right)\end{array}$ & $\begin{array}{c}\text { Wet } \\
\left(\mathrm{x} 10^{8}\right)\end{array}$ & $\begin{array}{c}\text { Dry } \\
\left(\mathrm{x} 10^{4}\right)\end{array}$ & $\begin{array}{c}\text { Wet } \\
\left(\mathrm{x} 10^{4}\right)\end{array}$ \\
\hline \multirow[t]{2}{*}{ Peanut/peanut } & Initial & $1.7 \mathrm{c}$ & 0.43 & 94cdef & $843.3 \mathrm{de}$ & 0.6 & $7.330 \mathrm{bcd}$ & $4.0 \mathrm{ij}$ & $4.0 \mathrm{~d}$ \\
\hline & Final & $4.3 \mathrm{abc}$ & 0.33 & $407 \mathrm{a}$ & $1.7 \mathrm{f}$ & 6.0 & $0.330 \mathrm{~d}$ & $160.0 \mathrm{a}$ & 2.0ef \\
\hline \multirow[t]{2}{*}{ Peanut/mixture } & Initial & $4.3 a b c$ & 0.83 & $167 \mathrm{~cd}$ & $1,080.0 \mathrm{bcd}$ & 1.0 & $3.670 \mathrm{~d}$ & $30.0 \mathrm{~d}$ & 2.0ef \\
\hline & Final & $8.3 \mathrm{a}$ & 0.67 & $477 \mathrm{a}$ & $7.3 \mathrm{f}$ & 3.4 & $0.330 \mathrm{~d}$ & $25.0 \mathrm{e}$ & $0.011 \mathrm{~h}$ \\
\hline \multirow[t]{2}{*}{ Peanut/grass } & Initial & $3.1 \mathrm{bc}$ & 0.30 & $18 \mathrm{ef}$ & $1,306.7 \mathrm{ab}$ & 2.4 & $1.000 \mathrm{~cd}$ & $17.5 \mathrm{f}$ & 1.7 efg \\
\hline & Final & $3.1 \mathrm{bc}$ & 0.33 & $83 \mathrm{def}$ & $6.3 \mathrm{f}$ & 0.7 & $0.001 \mathrm{~d}$ & $30.0 \mathrm{~d}$ & $0.0008 \mathrm{~h}$ \\
\hline \multirow[t]{2}{*}{ Mixture/peanut } & Initial & $0.7 \mathrm{c}$ & 0.37 & $27 \mathrm{ef}$ & $996.7 \mathrm{~cd}$ & 0.1 & $7.670 \mathrm{~cd}$ & $1.7 \mathrm{j}$ & $15.0 \mathrm{~b}$ \\
\hline & Final & $3.7 \mathrm{abc}$ & 0.33 & $110 \mathrm{cdef}$ & $53.0 \mathrm{f}$ & 1.2 & $3.330 \mathrm{~cd}$ & $175.0 \mathrm{f}$ & $0.2 \mathrm{~h}$ \\
\hline \multirow[t]{2}{*}{ Mixture/mixture } & Initial & $2.0 \mathrm{c}$ & 0.37 & $36 \mathrm{ef}$ & $1,570.0 \mathrm{a}$ & 0.2 & $17.000 \mathrm{~cd}$ & $2.0 \mathrm{j}$ & $2.5 \mathrm{e}$ \\
\hline & Final & $3.7 \mathrm{abc}$ & 0.67 & $173 \mathrm{bcd}$ & $21.7 \mathrm{f}$ & 1.3 & $0.001 \mathrm{~d}$ & 7.0hi & $0.8 \mathrm{fgh}$ \\
\hline \multirow[t]{2}{*}{ Mixture/grass } & Initial & $8.0 \mathrm{ab}$ & 0.17 & $11 \mathrm{f}$ & $693.7 \mathrm{e}$ & 0.1 & $1.670 \mathrm{~cd}$ & $3.0 \mathrm{ij}$ & $13.0 \mathrm{c}$ \\
\hline & Final & $1.3 \mathrm{c}$ & 0.01 & $53 \mathrm{ef}$ & $4.3 \mathrm{f}$ & 1.3 & $8.000 \mathrm{~d}$ & $20.0 \mathrm{f}$ & $0.0017 \mathrm{~h}$ \\
\hline \multirow[t]{2}{*}{ Grass/peanut } & Initial & $4.0 \mathrm{abc}$ & 0.40 & $192 b c$ & $1,273.3 \mathrm{bc}$ & 0.5 & $16.670 \mathrm{~b}$ & $14.0 \mathrm{~g}$ & $30.0 \mathrm{a}$ \\
\hline & Final & $4.0 \mathrm{abc}$ & 1.33 & $270 b$ & $12.0 \mathrm{f}$ & 2.9 & $43.330 \mathrm{a}$ & $90.0 \mathrm{~b}$ & $0.007 \mathrm{~h}$ \\
\hline \multirow[t]{2}{*}{ Grass/mixture } & Initial & $1.7 \mathrm{c}$ & 0.10 & $109 \mathrm{cdef}$ & $636.7 \mathrm{e}$ & 0.5 & $4.330 \mathrm{~cd}$ & $35.0 \mathrm{c}$ & $3.0 \mathrm{de}$ \\
\hline & Final & $1.0 \mathrm{c}$ & 1.40 & 47ef & $99.3 \mathrm{f}$ & 1.5 & $39.300 \mathrm{a}$ & $9.5 \mathrm{~h}$ & $0.2 \mathrm{~h}$ \\
\hline \multirow[t]{2}{*}{ Grass/grass } & Initial & $3.3 \mathrm{abc}$ & 0.77 & $22 \mathrm{ef}$ & $690.0 \mathrm{e}$ & 4.4 & $7.000 \mathrm{~cd}$ & $35.0 \mathrm{c}$ & $2.0 \mathrm{ef}$ \\
\hline & Final & $7.7 \mathrm{ab}$ & 1.33 & $113 \mathrm{cde}$ & $23.0 \mathrm{f}$ & 0.9 & $0.001 \mathrm{~d}$ & $1.7 \mathrm{j}$ & $0.5 \mathrm{gh}$ \\
\hline $\mathrm{CV}(\%)$ & & 18.9 & $\mathrm{~ns}$ & 23.88 & 30.01 & ns & 30.61 & 20.02 & 16.73 \\
\hline
\end{tabular}

${ }^{(1)}$ Means followed by the same letter in each column did not differ significantly at $5 \%$ probability level by the Tukey test. ${ }^{(2)}$ The final time was 160 and 80 days in the dry and wet season, respectively; numbers in parenthesis are the decimal of the number of colonies forming unite/g of dry litter.

P concentrations (Vasconcellos et al., 1997). On the other hand, these P-solubilizing microorganisms favor the release of $\mathrm{P}$ to soil solution.

Pinto peanut and mixed litters increased the release of nutrients, especially in the wet season (Table 4). However, immobilization of $\mathrm{N}$ was clearly observed on thatching grass litter in both seasons. The values of litter cellulose decomposition did not differ significantly among treatments. Higher nutrient concentrations in legume litters as compared to grass litters generally favor release of nutrients from legumes (Palm \& Sanchez, 1991; Thomas, 1995; Ayarza et al., 1998). During the wet season, the $\mathrm{N}$ and $\mathrm{P}$ half lives were also low in the mixed litter, especially in the grass monoculture (Table 5). The addition of pinto peanut to thatching grass litter in grass monoculture reduced the time of $\mathrm{N}$ release from 829.2 to 31.9 days, during the wet season, and the time of $\mathrm{P}$ release, from 39.1 to 22.8 days. Furthermore, the mixture of litters can reduce the $\mathrm{C} / \mathrm{N}$ and lignin/N ratios in grass (Palm \& Sanchez, 1991; Handayanto et al., 1997). The existence of a synergistic effect of the legume litter on the decomposition of the grass litter has been reported (Thomas \& Asakawa, 1993; Myers et al., 1997; Wardle et al., 1999). It is well established that the composition and
Table 4. Residual $\mathrm{P}(\mathrm{PR}), \mathrm{N}(\mathrm{NR})$ and cellulose (CR) in litters bags with Arachis pintoi (peanut) litter, Hyparrhenia rufa (grass) litter, mixture (peanut + grass) litter in single and intercropped plots after 160 and 80 days during dry and wet seasons, respectively. Values are expressed as percentage of the initial values ${ }^{(1)}$.

\begin{tabular}{|c|c|c|c|c|c|c|}
\hline \multirow{2}{*}{$\begin{array}{l}\text { Treatment } \\
\text { (plot/litter bag) }\end{array}$} & \multicolumn{2}{|c|}{ PR } & \multicolumn{2}{|c|}{ NR } & \multicolumn{2}{|c|}{$\mathrm{CR}$} \\
\hline & Dry & Wet & Dry & Wet & Dry & Wet \\
\hline Peanut/peanut & $62.91 \mathrm{a}$ & $3.50 \mathrm{~d}$ & $46.59 \mathrm{~b}$ & $6.39 \mathrm{~b}$ & $96.61 \mathrm{a}$ & $57.27 \mathrm{a}$ \\
\hline Peanut/mixture & $78.43 \mathrm{a}$ & $9.76 \mathrm{~cd}$ & $61.03 \mathrm{ab}$ & $14.86 \mathrm{~b}$ & $104.22 \mathrm{a}$ & $32.60 \mathrm{a}$ \\
\hline Peanut/grass & $74.35 \mathrm{a}$ & $31.93 \mathrm{a}$ & $80.48 \mathrm{ab}$ & $79.66 \mathrm{a}$ & $82.70 \mathrm{a}$ & $50.39 \mathrm{a}$ \\
\hline Mixture/peanut & $66.15 \mathrm{a}$ & $5.94 \mathrm{~d}$ & $60.47 \mathrm{ab}$ & $11.71 \mathrm{~b}$ & $116.36 \mathrm{a}$ & $58.15 \mathrm{a}$ \\
\hline Mixture/mixture & $64.11 \mathrm{a}$ & $11.38 \mathrm{~cd}$ & $52.76 \mathrm{ab}$ & $21.00 \mathrm{~b}$ & $93.32 \mathrm{a}$ & $48.04 \mathrm{a}$ \\
\hline Mixture/grass & $73.07 \mathrm{a}$ & $27.12 \mathrm{ab}$ & $83.12 \mathrm{ab}$ & $75.76 \mathrm{a}$ & $94.41 \mathrm{a}$ & $57.45 \mathrm{a}$ \\
\hline Grass/peanut & $73.06 \mathrm{a}$ & $3.22 \mathrm{~d}$ & $50.50 \mathrm{ab}$ & $6.79 b$ & $88.17 \mathrm{a}$ & $63.94 \mathrm{a}$ \\
\hline Grass/mixture & $73.61 \mathrm{a}$ & $8.84 \mathrm{~cd}$ & $59.08 \mathrm{ab}$ & $17.56 \mathrm{~b}$ & $99.65 a$ & $62.02 \mathrm{a}$ \\
\hline Grass/grass & $63.34 \mathrm{a}$ & $23.93 \mathrm{ab}$ & $89.02 \mathrm{a}$ & $99.23 \mathrm{a}$ & $101.36 \mathrm{a}$ & $58.09 \mathrm{a}$ \\
\hline
\end{tabular}

${ }^{(1)}$ Means followed by the same letter in each column did not differ significantly at $5 \%$ probability level, by the Tukey test; the coefficients of variation for PR in the wet season and for NR in the dry and wet seasons were $19.43 \%, 16.44 \%$ and $20.62 \%$, respectively.

the activity of soil microflora depend on the quality of litter (Robertson \& Morgan, 1996; Handayanto et al., 1997; Heal et al., 1997; Wardle \& Lavelle, 1997; Wardle et al., 1999).

There was no correlation between mass (RM) and $P$ release during the dry season (Table 6). During the wet season, significant correlations were observed for pinto peanut and mixed litters with $r$ values 
Table 5. Decay Rate Constant for $\mathrm{N}$ and $\mathrm{P}(\mathrm{KN}, \mathrm{KP})$ and half-lives of $\mathrm{N}$ and $\mathrm{P}$ release $\left(\mathrm{T}_{1 / 2} \mathrm{~N}, \mathrm{~T}_{1 / 2} \mathrm{P}\right)$ in litter bags with Arachis pintoi (peanut) litter, Hyparrhenia rufa (grass) litter, mixture (peanut + grass) litter in single and intercropped plots after 160 and 80 days during dry and wet seasons, respectively ${ }^{(1)}$.

\begin{tabular}{|c|c|c|c|c|c|c|c|c|}
\hline \multirow{2}{*}{$\begin{array}{l}\text { Treatment } \\
\text { (plot/litter bag) }\end{array}$} & \multicolumn{2}{|c|}{$\mathrm{KN}\left(\right.$ days $\left.^{-1}\right)$} & \multicolumn{2}{|c|}{$\mathrm{KP}\left(\right.$ days $\left.^{-1}\right)$} & \multicolumn{2}{|c|}{$\mathrm{T}_{1 / 2} \mathrm{~N}$ (days) } & \multicolumn{2}{|c|}{$\mathrm{T}_{1 / 2} \mathrm{P}$ (days) } \\
\hline & Dry & Wet & Dry & Wet & Dry & Wet & Dry & Wet \\
\hline Peanut/peanut & $0.006 \mathrm{a}$ & $0.036 \mathrm{a}$ & $0.003 \mathrm{a}$ & $0.044 \mathrm{ab}$ & $112.0 \mathrm{c}$ & $19.8 \mathrm{c}$ & $180.1 \mathrm{a}$ & $16.1 \mathrm{~d}$ \\
\hline Peanut/mixture & $0.004 \mathrm{a}$ & $0.025 \mathrm{ab}$ & $0.002 \mathrm{a}$ & $0.029 \mathrm{ab}$ & $174.2 \mathrm{c}$ & $29.1 \mathrm{c}$ & $424.3 \mathrm{a}$ & $23.8 \mathrm{~cd}$ \\
\hline Peanut/grass & $0.001 \mathrm{a}$ & $0.003 \mathrm{c}$ & $0.002 \mathrm{a}$ & $0.015 b$ & $557.8 \mathrm{~b}$ & $465.4 \mathrm{~b}$ & $318.0 \mathrm{a}$ & $49.3 \mathrm{a}$ \\
\hline Mixture/peanut & $0.004 \mathrm{a}$ & $0.031 \mathrm{a}$ & $0.003 \mathrm{a}$ & $0.038 \mathrm{ab}$ & $167.2 \mathrm{c}$ & $25.3 \mathrm{c}$ & $204.5 \mathrm{a}$ & $19.1 \mathrm{~d}$ \\
\hline Mixture/mixture & $0.005 \mathrm{a}$ & $0.020 \mathrm{ab}$ & $0.003 \mathrm{a}$ & $0.027 \mathrm{ab}$ & $130.5 \mathrm{c}$ & $36.2 \mathrm{c}$ & $191.8 \mathrm{a}$ & $25.5 \mathrm{bcd}$ \\
\hline Mixture/grass & $0.001 \mathrm{a}$ & $0.003 \mathrm{c}$ & $0.002 \mathrm{a}$ & $0.016 \mathrm{ab}$ & $886.7 \mathrm{a}$ & $202.9 \mathrm{~b}$ & $268.3 \mathrm{a}$ & $42.7 \mathrm{ab}$ \\
\hline Grass/peanut & $0.005 \mathrm{a}$ & $0.036 \mathrm{a}$ & $0.005 \mathrm{a}$ & $0.045 \mathrm{a}$ & $122.8 \mathrm{c}$ & $20.2 \mathrm{c}$ & $139.6 \mathrm{a}$ & $15.8 \mathrm{~d}$ \\
\hline Grass/mixture & $0.004 \mathrm{a}$ & $0.022 \mathrm{ab}$ & $0.003 \mathrm{a}$ & $0.030 \mathrm{ab}$ & $159.2 \mathrm{c}$ & $31.9 \mathrm{c}$ & $283.9 \mathrm{a}$ & $22.8 \mathrm{~cd}$ \\
\hline Grass/grass & $0.001 \mathrm{a}$ & $0.0001 \mathrm{~d}$ & $0.004 \mathrm{a}$ & $0.018 \mathrm{ab}$ & $567.9 \mathrm{~b}$ & $829.2 \mathrm{a}$ & $216.5 \mathrm{a}$ & $39.1 \mathrm{abc}$ \\
\hline
\end{tabular}

${ }^{(1)}$ Means followed by the same letter in each column did not differ significantly at $5 \%$ probability level by the Tukey test.

Table 6. Pearson correlation coefficients of mass loss (RM) and $\mathrm{P}$ release (PR) during dry and wet seasons.

\begin{tabular}{lcl}
\hline $\begin{array}{l}\text { Treatment } \\
\text { (plot/litter bag) }\end{array}$ & Dry & Wet \\
\hline Peanut/peanut & $-0.33^{\mathrm{ns}}$ & $0.98^{* *}$ \\
Peanut/mixture & $-0.50^{\mathrm{ns}}$ & $0.79^{* *}$ \\
Peanut/grass & $-0.14^{\mathrm{ns}}$ & $0.42^{\mathrm{ns}}$ \\
Mixture/peanut & $-0.30^{\mathrm{ns}}$ & $0.98^{* *}$ \\
Mixture/mixture & $-0.27^{\mathrm{ns}}$ & $0.95^{* *}$ \\
Mixture/grass & $0.41^{\mathrm{ns}}$ & $0.63^{*}$ \\
Grass/peanut & $0.43^{\mathrm{ns}}$ & $0.98^{* *}$ \\
Grass/mixture & $-0.08^{\mathrm{ns}}$ & $0.97^{* *}$ \\
Grass/grass & $0.19^{\mathrm{ns}}$ & $0.47^{\mathrm{ns}}$ \\
\hline
\end{tabular}

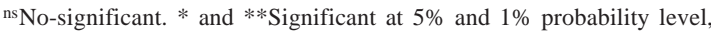
respectively.

over 0.79 . The P release probably was influenced for favorable conditions for P-solubilizing microorganisms activities. In pinto peanut and mixed litters, the efficient release of $\mathrm{P}$ coincided with that of $\mathrm{N}$, showing the high potential for nutrient recycling by pinto peanut litter in lowland soil and may be used to recover degraded soils.

\section{Conclusions}

1. About 272.17 days are necessary for $50 \%$ of Arachis pintoi decomposition, during dry season and 20.38 days during wet season, under grass plots degraded; about 122.8 and 139.6 days are necessary for $A$. pintoi to release $50 \%$ of $\mathrm{N}$ and $\mathrm{P}$, respectively, in the dry season, and 20.2 and 15.8 days in the wet season, under the same plots.

2 . The content of cellulose, and the lignin/ $\mathrm{N}$ and $\mathrm{C} / \mathrm{N}$ rations influence the decomposition of the A. pintoi and Hyparrhenia rufa residues.
3 . The decomposition rate and release of nutrients of the $H$. rufa litter are reduced $50 \%$ after the addition of $A$. pintoi litter and are influenced by favorable lignin/ $\mathrm{N}$ and $\mathrm{C} / \mathrm{N}$ ratios of pinto peanut litter.

\section{Acknowledgements}

To Renato Simões, for the chemical analysis; to Fapemig, for the financial support.

\section{References}

AYARZA, M. A.; VILELA, L.; PIZARRO, E. A. Estratégias de cultivo de milho (Zea mays) sobre cobertura permanente de A. pintoi. Pasturas Tropicales, Cali, v. 20, p. 28-29, 1998.

CHANG, Y.; HUDSON, H. J. The fungi of wheat straw compost - I: ecological studies. Transactions of the British Mycological Society, Cambridge, England, v. 50, p. 667-677, 1967.

CORNEJO, F. H.; VARELA, A.; WRIGHT, S. J. Tropical forest litter decomposition under seasonal drought: nutrient release, fungi and bacteria. Oikos, Copenhagen, v. 70, p. 183-190, 1994.

ENTRY, J. A.; BACKMAN, C. B. Influence of carbon and nitrogen on cellulose and lignin degradation in forest soils. Canadian Journal of Forest Research, Ottawa, v. 25, p. 1231-1236, 1995.

FERGUSON, J. E. Experiences at the interface of research and development with tropical pastures. In: CENTRO 
INTERNACIONAL DE AGRICULTURA TROPICAL (Cali, Colombia). Pastures for the tropical lowlands: CIAT's contribution. Cali, 1992. p. 101-120.

GROFFMAN, P. M.; EAGAN, P.; SULLIVAN, W. M.; LEMUNYON, J. L. Grass species and soil type effects on microbial biomass and activity. Plant and Soil, Dordrecht, v. 183, n. 1, p. 61-67, 1996.

HANDAYANTO, E.; CADISH, G.; GILLER, K. E. Regulating $\mathrm{N}$ mineralization from plant residues by manipulation of quality. In: CADISH, G.; GILLER, K. E. (Ed.). Driven by nature: plant litter quality and decomposition. Wallingford: CAB International, 1997. p. 175-186.

HEAL, O. W.; ANDERSON, J. M.; SWIFT, M. J. Plant litter quality and decomposition: an historical overview. In: CADISH, G.; GILLER, K. E. (Ed.). Driven by nature: plant litter quality and decomposition. Wallingford: CAB International, 1997. p. 3-32.

MACEDO, M. C. M. Pastagens no ecossistema Cerrado: pesquisas para o desenvolvimento sustentável. In: SIMPÓSIO SOBRE PASTAGENS NOS ECOSSISTEMAS BRASILEIROS, 1995, Brasília. Anais... Brasília: Sociedade Brasileira de Zootecnia, 1995. p. 28-62.

MYERS, R. J. K.; NOODWIJK, M. van; VITYAKON, P. Synchrony of nutrient release and plant demand: plant litter quality: soil environmental and farmer management options. In: CADISH, G.; GILLER, K. E. (Ed.). Driven by nature: plant litter quality and decomposition. Wallingford: CAB International, 1997. p. 215-230.

OKEKE, A. J.; OMALIKO, C. P. E. Leaf litter decomposition and carbon dioxide evolution of some agroforestry fallow species in Southern Nigeria. Forest Ecology Management, Amsterdam, v. 50, p. 103-116, 1992.

OLIVEIRA, C. A.; SCOTTI, M. R. M. M. L.; PURCINO, H. A.; VASCONCELLOS, C. A.; MARRIEL, I. E.; SÁ, N. M. H. Decomposition of Arachis pintoi litter intercropped with forage grass in "Cerrado" soil in the dry and wet seasons. Biology and Fertility of Soils, Berlin, v. 36, p. 405-410, 2002.

OLIVEIRA, S. A. Método simplificado para determinação colorimétrica de nitrogênio em plantas. Ciência e Cultura, São Paulo, v. 38, p. 178-180, 1986.

OLSON, J. S. Energy storage and the balance of producers and decomposers in ecological systems. Ecology, Durham, v. 44, p. 322-331,1963.

PALM, C. A.; SANCHEZ, P. A. Nitrogen release from the leaves of some tropical legumes affected by their lignin and polyphenolic contents. Soil Biology and Biochemistry, Oxford, v. 23, p. 83-88, 1991.

PARKINSON, D.; GRAY, T. R. G.; WILLIAMS, S. T. Isolation of micro-organisms. In: PARKINSON, D.; GRAY, T. R. G.; WILLIAMS, S. T. (Ed.). Methods for studying the ecology of soil micro-organisms. London: Blackwell, 1971. p. 36-56 (IPI Handbook, 19).

ROBERTSON, F. A.; MORGAN, W. C. Effects of management history and legume green manure on soil microorganisms under organic vegetable production. Australian Journal of Soil Research, Collingwood, v. 34, p. 427-440, 1996.

SARRUGE, J. R.; HAAG, H. P. Análises químicas em plantas. Piracicaba: Esalq, 1974. 56 p.

SMITH, J. L. Cycling of nitrogen through microbial activity. In: HATFIELD, J. L.; STEWART, B. A. (Ed.). Soil biology: effects on soil quality. Boca Raton: CRC Press, 1994. p. 91-120.

SOEST, P. J. van. Use of detergents in the analysis of fibrous feeds - II: a rapid method for the determination of fiber and lignin. Journal of the Association of Official Agricultural Chemists, Washington, v. 46, p. 829835,1963 .

SWIFT, M. J. Species diversity and the structure of microbial communities in terrestrial habitats. In: ANDERSON, J. M.; MacFADYEN, A. (Ed.). The role of terrestrial and aquatic organisms in decomposition processes. Oxford: Blackwell, 1976. p. 185-222.

SWIFT, M. J.; HEAL, O. W.; ANDERSON, J. M. Decomposition in terrestrial ecosystems: studies in ecology. Oxford: Blackwell, 1979. 372 p.

THOMAS, R. J. Rhizobium requirements, nitrogen fixation and nutrient cycling in forage Arachis. In: CENTRO INTERNACIONAL DE AGRICULTURA TROPICAL (Cali, Colombia). Biology and agronomy of forage Arachis. Cali, 1993. p. 84-94.

THOMAS, R. J. Role of legumes in providing N for sustainable tropical pasture systems. Plant and Soil, The Hague, v. 174, p. 103-118, 1995. 
THOMAS, R. J. The role of the legume in nitrogen cycle of productive and sustainable pastures. Grass and Forage Science, Oxford, v. 47, p. 133-142, 1992.

THOMAS, R. J.; ASAKAWA, N. M. Decomposition of leaf litter from tropical forage grasses and legumes. Soil Biology and Biochemistry, Oxford, v. 25, p. 1351-1361, 1993.

TIAN, G. Effects of soil degradation on leaf decomposition and nutrient release under humid tropical conditions. Soil Science, Baltimore, v. 163, n. 11, p. 897-906, 1998.

VASCONCELLOS, C. A.; PURCINO, H.; VIANNA, M. C. M.; FRANÇA, C. C. M. Nutrição mineral do Arachis pintoi. Pasturas Tropicales, Cali, v. 18, n. 3, p. 50 53, 1997.
WARDLE, D. A.; GILLER, K. E.; BARKER, G. M. The regulation and functional significance of soil biodiversity in agroecosystems. In: WOOD, D.; LENNÉ, J. M. (Ed.). Agrobiodiversity: characterization, utilization, and management. Wallingford: CAB International, 1999. p. 87-121.

WARDLE, D. A.; LAVELLE, P. Linkages between soil biota, plant litter quality and decomposition. In: CADISH, G; GILLER, K. E. (Ed.). Driven by nature: plant litter quality and decomposition, Wallingford. CAB International, 1997. p. $107-124$.

WESEMAEL, B. V. Litter decomposition and nutrient distribution in humus profiles in some Mediterranean forests in southern Tuscany. Forest Ecology Management, Amsterdam, v. 57, p. 99-114, 1993. 